\title{
The Inheritance and Spreading of Confucianism in Modern China and South Korea
}

\author{
Ya Xiao \\ School of International Studies, \\ Zhejiang University, \\ Hangzhou, China
}

\author{
Jie $\mathrm{Hu}^{*}$ \\ School of International Studies, \\ Zhejiang University, Hangzhou, China \\ *Corresponding author, huj@zju.edu.cn
}

\begin{abstract}
Confucianism has influenced the regulating of family relations, the maintaining of social order, and the promoting of national spirit for thousands of years in the East Asian cultural circle. Though Confucianism originates in China, it is not inherited and spread as successful as in South Korea nowadays. This study applies the qualitative analysis to investigate the underlying reasons for different situations of Confucian cultural preservation between modern China and South Korea. The findings are (1) compared with China where several radical movements in modern times started from the Taiping Heavenly Kingdom Movement have dealt a serious blow to the status of Confucianism, Korean witnessed a rather moderate process of Confucianism development. (2) Korea lays great emphasis on moral education of Confucianism, while academic achievement seems to be prioritized in China's teaching activities. (3) Korea takes full advantage of mass media to popularize Confucianism, the degree of which hasn't been realized in China. These practices in Korea shed light on China to better improve the culture soft power embodied in Confucianism in modernization.
\end{abstract}

Keywords-Confucianism; cultural inheritance and spreading; culture soft power; China; South Korea

\section{INTRODUCTION}

China and South Korea are close neighbors separated only by a strip of water, both of whom belong to the East Asian cultural circle. Confucianism originated in China and was introduced to South Korea at the end of the first century BC. In both cultures, Confucianism has played a significant role in regulating family relations, maintaining social order, and promoting the national spirit for thousands of years [1]. Yet, in the $21^{\text {st }}$ century, when western culture prevails around the globe, it seems that the status quo of the inheritance of Confucianism is different in two countries.

It's not a rare occurrence that Korean young generation still adheres to the creed of Confucianism in daily practice, which, however, gradually it fades out of Chinese young people's life. To illustrate, Korean students would bow to the seniors while some Chinese students wouldn't even properly greet their teacher at school. What lies behind the gap of Confucianism development in two cultures? How does South Korea perfectly integrate Eastern and Western cultures? As the birthplace of Confucianism, China should take Korea's way of preserving Confucianism into careful consideration in the process of

Supported by the Central Universities Foundation of Zhejiang University.

*Corresponding Author: Jie Hu, huj@zju.edu.cn, ORCID:

http://orcid.org/0000-0003-2219-2587 building socialist modernization with Chinese characteristics since this ideology has a far-reaching influence on realizing national rejuvenation.

\section{REASONS FOR DIFFERENCES IN THE INHERITANCE OF CONFUCIANISM IN TWO CULTURES}

\section{A. Comparison and contrast in ideological status}

Since Confucianism was introduced to South Korea, it has always been in the mainstream of Korean culture. According to what was recorded in Samguk sagi-Goguryeo (Chronicles of the Three Kingdoms), the central Confucian educational institution "Tai Xue" and the local one "Yu Tang" were established to recruit students. Confucian classics were the main teaching content. After that, Confucianism was acknowledged as the official orthodoxy in Goguryeo [2]. By the end of the 13th century, neo-Confucianism proposed by Cheng Hao, Cheng Yi, and Zhu Xi was introduced to South Korea. Confucianism was further developed by Korean Confucianists Li Huang and Li Gu.

Japan implemented a series of assimilation policies on the Korean peninsula during the 30-year colonial period, from encroaching on land and plundering manpower to ideological invasion. Even so, Korea didn't degenerate into a subordinate to Japanese culture [3]. In this regard, Korean people have always had a deep understanding of national homogeneity because they stick to Confucianism. After the Second World War, it can be said that the status of Confucianism was never radically challenged in history. Nowadays, Confucianism has integrated into the national character of Korea. Korean people treasure Confucian ethics and morality as their spiritual strength.

In China, Confucianism has stretched for over two centuries since Spring and Autumn period during which Confucius lived. Although emperor Qin once burned Confucian classics and buried Confucian scholars alive, Dong Zhongshu in western Han dynasty restored the dominance of Confucianism in feudal society by promoting the policy of proscribing all non-Confucian schools and espousing Confucianism as the orthodox state ideology.

On the contrary, modern times have witnessed the devastating blows targeted at Confucianism several times. The leader of Taiping Heavenly Kingdom Movement, Hong Xiuquan founded the Taiping Christianity whose main theory 
is to worship God, trying to replace traditional Confucianism. Later, Yang Wu Movement and Hundred Days Reform in the late Qing dynasty further weakened the status of Confucianism by spreading western learning. The New Culture Movement initiated by Hu Shi, Chen Duxiu, Lu Xun, Qian Xuantong, Li Dazhao and other young people who have received Western education set off the first large-scale anti-Confucianism movement when the orthodox status of Confucianism began to waver. During the Cultural Revolution period, Confucianism was completely criticized as a reactionary and decaying school. After that, Confucianism completely lost its orthodox status and was increasingly marginalized in modern society. According to Professor Du Weiming, a representative of NeoConfucianism, "Confucianism was largely cut off from the life of the young generation was due to these radical antiConfucianism movements in modern times” [4].

\section{B. Differences in confucian education}

There seems to be no country like Korea, where moral education is so emphasized in the formal education system. As early as 1960, South Korea put Confucian culture into the moral class from primary school to college. In the process of promoting national spiritual education, South Korea has always used traditional culture, especially Confucian culture as a carrier. The Korean junior high school moral class infiltrates the Confucian cultural tradition, requiring students to honor their parents, respect their teachers, and live in harmony with their classmates. The national ethics course in college draws on the essence of Confucian culture, conducting education on selfreliance and self-determination to achieve the goal of strengthening the country. After the Asian financial turmoil, South Korea put forward the national policy of "culture orientated national development" to fully tap the essence of Confucian culture and integrate it into modern life.

The influence of Confucian culture on education is particularly significant in the academic discipline setup in higher education. Sungkyunkwan University, Seoul National University, Korea University, Yonsei University, and many other universities open special discipline on Confucianism and establish corresponding research institutions. The "Shudian Festival" of Confucius is held by more than 300 township schools distributed throughout the country have the reputation of "Confucianism University". On September 28th of each year, the festival to worship Confucius is held at the Sungkyunkwan University and nearly 300 township schools across the country.

While in China, moral education is dispensable, even seen as an academic burden in the eyes of students. Test-oriented education forces students to devote most of their spare time to major courses such as Chinese, English, and Mathematics. The moral class is notoriously known as a course for rote learning. A number of students complain that what has been taught in the moral class is merely a theory written in classics, which cannot be applied in daily life. Also, the infusion way of teaching would lower their interest in knowing the essence of these teachings. In this case, the moral class becomes a compulsory course to deal with the college entrance examination, rather than guidance with lifelong benefits [5]. In college, moral education becomes a mere formality without pressure from tests. In the face of more temptation from the material wealth compared with high school, the students gradually ignore the pursuit of traditional moral values, or even overwhelmed by the craze for materials. During this period, the gap between knowledge and action in moral psychology and education becomes even sharper [6-8]. This process is where Confucian culture loses in the young generation of China. Research on Confucianism is unpopular among students, which causes the dilemma of uninherited Confucianism.

\section{Differences in ways of spreading Confucianism}

South Korea makes full use of the power of mass media to spread Confucianism, particularly in family ethics drama. For instance, Korean TV dramas such as “1988”, promoting the family ethics of Confucianism with realistic methods. In this drama, the relationships between parents and children, between neighbors and friends are used as carriers for the family culture promoted by Confucianism. Although the main characters in the drama are ordinary people, they shape the national image of Korea carrying Confucianism with their own efforts in daily life. In particular, young teenagers will always give regards to the elders after school no matter how indulgent they are in the puberty. Parents would require children not to eat before the elders and not to make noise during meals. When drinking, young people could not toast with the elders without getting permission and the cup must be held with their left hand since the left hand is considered humble compared with the right hand. In addition, honorific Korean is a must in addressing strangers in order to show humility, as shown in the drama. The audience will find their own projections in life from the realistic settings in the drama. The values of etiquette, integrity, loyalty, and love are constantly underlined over and over again, which allows Confucian culture to be infiltrated in the plot of the TV series to reach the audience's heart deeply and smoothly. This kind of Korean-style way of spreading the ideology of benevolence, morality, and filial piety attract a great number of audience home and abroad [9].

While contemporary Chinese family ethics dramas also embody Confucianism presented in a unit of the family in the play. However, the contradictions between the mother and the daughter-in-law, the preference of boys over girls, the spoiling of the parents to the children, etc., are overstated in the play. Obviously, it deepens people's dislike of the three cardinal principles governing the relationships between ruler and minister, father and son, husband and wife, and the five constant virtues including humanity, righteousness, propriety, wisdom, and fidelity in Confucianism. China's utilization of the booming cultural market to spread Confucianism and strengthen cultural confidence is not enough compared with Korea. What's worse, China's popular culture focuses too much on entertainment, which has destroyed the Confucianism culture as never before. The time-travel drama subverting the basic historical facts, in turn, attracts the popularity among teenagers, which certainly will mislead them to regard the plot in the play as real history.

The phenomenon that Korean family ethics dramas are widely accepted by the Chinese audience reflects that Chinese people call for Confucian culture emotionally and psychologically. The essence of Confucianism, that is, loyalty, filial piety, righteousness, and sincerity, can still arouse 
sympathy among the young generation as long as it finds the right carrier. In the contemporary circumstance, digitization provides a dynamic method to communicate traditional Chinese culture as Confucianism with a diverse audience from a different cultural background, which deserves particular attention from the Chinese media workers [10].

\section{CONCLUSIONS AND DISCUSSIONS}

In general, Confucianism is better preserved in modern Korea than China, which may be traced to that (1) different from China, few radical movements have ever challenged the dominant status of Confucianism in Korea. (2) Korea lays greater emphasis on the moral education of Confucianism by curriculum design and teaching facilities building. (3) Mass media is appropriately utilized to popularize Confucianism in Korea.

Therefore, Korean's practices in preserving Confucianism that originates in China deserve to be analyzed carefully and learned immediately. The Chinese need to reflect upon the current problems in Confucianism inheritance and spreading and take immediate measures to find a place for the renewed Confucianism to function as an inevitable and socially positive part of people's life. In particular, it is necessary not only to develop the intelligence of students, but also to cultivate their morality, in which Confucian teaching is an essential link. As for the methods of Confucianism teaching, it is not supposed to be a theoretical infusion, but to be combined perfectly with reality. For example, educators can encourage students to construct their own understanding rather than reproduce the thoughts of teachers, which accords with the key connotation of Confucius teaching method [11].

Concerning the curriculum provision, courses on morality are supposed to be included as a major course with longer teaching hours per week and higher quality of teaching compared with the current situation. Only students, who have received the systematic education in morality as well as intelligence, can be regarded as a qualified successor of the great socialist cause.

In terms of the choice of teaching contents, historical materials should be paid more attention. China is one of the four ancient civilizations in the world. It boasts a long history and splendid culture. The ancestors have left contemporary people with countless precious cultural heritage, whether physical or spiritual. It is the responsibility to make contributions to the promotion of the excellent traditional culture. When choosing curriculum contents, the spirit of valuing history should be upheld. The excavation of historical resources will definitely shed light on unsolved problems nowadays. Only by reviewing history can the students grasp the present and look forward to the future. Therefore, Confucian classics such as Analects are suggested to be included in the textbooks. Meanwhile, in the long history of education, it can be found that in any case of successful education, the curriculum contents must not be drawn from single resources. In the course of developing a course, it is not enough to only collect historical resources. Resources of the present generation should also be selected. The interpretations of Confucian classics from the modern writers and critics like
Yu Dan are also a good choice. In this case, works of foreign sinologists such as John. H. Berthrong are a significant channel for Chinese students to have a vision of the international influence of Confucianism. Generally, allowing students to have a comprehensive understanding of Confucianism from the past and the present, from home and abroad is the standard of high-quality Confucian teaching contents.

With regards to the spreading of Confucianism, it is advised to encourage the building of Confucius institutes for the purpose of expanding the influence of Chinese culture. In face of the shortage of qualified talents in the teaching of Chinese as a foreign language, the construction of Confucius institutes as an official institute for teaching Chinese and Confucianism will not only provide many job opportunities, but also attract foreigners to learn about Chinese culture and Confucian thoughts due to the brand effect. Every student of the Confucian institutes will serve as a communicator of Confucianism, and make his or her own contribution to the spreading of Confucianism.

Additionally, it is time to utilize multimedia means to digitally present Confucian thoughts and spread Confucianism. In detail, a resource database that integrates Confucian classics, experts' Confucian lectures, Confucian cultural promotion activities, and Confucian historical sites can be built with the aid of multimedia. Meanwhile, Confucian-themed film, television dramas, reality shows, quiz shows as well as a series of educational animated works of Confucian culture can be produced to cultivate people. Also, a digital museum of representatives of Confucianism can be established to attract more audience. And the applications for the learning of Confucius's sayings and the stories between Confucius and his students can be designed and launched for the instant learning of Confucian thoughts. In addition, digital advertisements can be utilized to reflect upon the spirit of comity and harmony in Confucian thoughts in the way of blending people, feelings, and scenery. The digital spreading of Confucianism is both innovative and effective against the background of globalization [12-14]. At the same time, effective and in-time monitoring of the spreading of Confucianism via multimedia is also needed [15-17]. For instance, the emojis that spoof Confucius and the comments that twist Confucius's sayings through social media home and abroad are supposed to be immediately suppressed considering the influence of social media in manipulating public opinions. Otherwise, teenagers who cannot distinguish right from wrong would easily be misled, and they would not show due respect for the traditional Confucian culture.

Confucianism is an essential part of Chinese traditional culture, the influence of which has expanded from China to the whole East Asian cultural circle. However, the inheritance and spreading of Confucianism in modern China are not as good as expected, particularly in comparison with modern Korea. Therefore, the successful practices in Korea will offer insights for China to better integrate Confucianism into modernization. Suggestions are given based on the detailed analysis of the situation of Confucianism development in modern China and Korea, especially in terms of educational promotion and digital spreading. 


\section{ACKNOWLEDGMENT}

The authors gratefully acknowledge the research project supported by the Central Universities Foundation of Zhejiang University.

\section{REFERENCES}

[1] Q. Y. Kang, "Connotation, Characteristics and Functions of National Spirit,” In the Chinese National Spirit. Singapore: Springer, 2017, pp. 39-80.

[2] D. Y. Kwon, J. P. Tamang, "Religious ethnic foods," Journal of Ethnic Foods, vol. 2, pp. 45-46, 2015

[3] M. E. Caprio, "The politics of assimilation: Koreans into Japanese," In Routledge Handbook of Modern Korean History, J. S. Michael, Eds. London: Routledge, 2016, pp. 111-123.

[4] W. M. Tu, "On the modernization of the Confucian traditions," Journal of Zhejiang University, vol. 34, pp. 5-12, 2004.

[5] T. Zhang, "Problems of Moral Education in China's schools and Solutions," Sociology Study, vol. 7, pp. 325-330, 2017.

[6] C. Darnell, L. Gulliford, K. Kristjánsson, P. Paris, "Phronesis and the knowledge-action gap in moral psychology and moral education: A new synthesis?” Human Development, pp. 1-29, 2019.

[7] J. Hu, Y. Wei, Y. The centrality of creativity: A new perspective on English language teaching. English Today, vol. 35, pp. 60-62, 2018.

[8] J. Chen, Y. Zhang, Y. Wei, J. Hu, "Discrimination of the contextual features of top performers in scientific literacy using a machine learning approach,” Research in Science Education, https://rdcu.be/btN56, in press, 2019.
[9] B. Jackson, "Confucianism and Korean dramas: How cultural and social proximity, hybridization of modernity and tradition, and dissimilar Confucian trajectories affect importation rates of Korean broadcasting programs between Japan and China,” Auctus, vol. 42, pp. 1-14, 2017.

[10] Y. L. Zhang, Y. Muhammad, Y. Q. Xu, "Chinese traditional culture and art communication in digital era: Strategies, issues, and prospects," Journal of Media Studies, vol. 32, pp. 61-75, 2017.

[11] G. Sigurðsson, "Transformative critique: What Confucianism can contribute to contemporary education," Studies in Philosophy and Education, vol. 36, pp. 131-146, 2017.

[12] H. Liu, "The inheritance and application of Confucian culture in digital interactive advertising design in Southeast Asia," International Conference on Social Science, Management and Economics (SSME). Wuhan, pp. 39-44, 2017.

[13] J. Chen, J. Hu, "Enhancing L2 learners' critical thinking skills through a connectivism-based intelligent learning system," International Journal of English Linguistics, vol. 8, pp. 12-21, 2018.

[14] Y. Wei, Q. Yang, J. Chen, J. Hu, "The exploration of a machine learning approach for the assessment of learning styles changes," Mechatronic Systems and Control, vol. 46, pp. 121-126, 2018.

[15] Y. Wei, J. Hu, "Differentiating critical thinking dispositions of newly enrolled EFL undergraduates and postgraduates through a support vector machine approach," Mechatronic Systems and Control, vol. 47, 2019

[16] X. Chen, Y. Yan, J. Hu, "A corpus-based study of Hillary Clinton's and Donald Trump's linguistic styles,” International Journal of English Linguistics, vol. 9, pp. 12-21, 2019.

[17] Y. Xiao, Y. Li, J. Hu, "Construction of the Belt and Road Initiative in Chinese and American media: A critical discourse analysis based on self-built corpora,” International Journal of English Linguistics, vol. 9, pp. 68-77, 2019 